\title{
Things that Don't Come by the Road: Folktales, Fosterage, and Memories of Slavery in the Cameroon Grassfields
}

\author{
NICOLAS ARGENTI
}

Brunel University

Might we not say that every child at play behaves like a creative writer, in that he creates a world of his own, or rather, rearranges the things of his world in a new way which pleases him?

Freud (1959 [1908]: 143-44)

Sweet mother I no go forget you for de suffer weh you suffer for me, yea.

Prince Nico Mbarga, "Sweet Mother" (1976)

FəNGAANEN-OO ...

Oku adults have a straightforward rationalization for the existence of folktales:

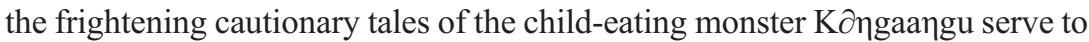
warn children not to go to the fields or to stray too far from the house without their parents. But this rationalization is belied by the fact that adults in this chiefdom of the Cameroon Grassfields do not tell folktales to children. Rather, folktales are most often told by children amongst each other, with no adult involvement, and they are consequently learned by younger children

This paper has benefited from presentation at the following events: The "Landscapes of Violence: Memory and Sacred Space" workshop at Martin Luther University Halle; the "African Children in Focus: A Paradigm Shift in Methodology and Theory?" NVAS conference, Leiden, the Department of Anthropology Stockholm University; the panel "Intimacy and Violence," at the CASCA-AES conference in Vancouver 2009; and the "Tales of Slavery" conference at the University of Toronto 2009. I thank the following people for organizing these events and for their feedback: Erdmute Alber, Karin Barber, Maurice Bloch, Filip de Boeck, Julien Bonhomme, Judith Bovensiepen, Andreas Eckert, Sandra Evers, Sverker Finnström, Silvia Forni, Sjaak van der Geest, Peter Geschiere, Janine Klungel, Martin Klein, Katrien Notermans, Michael Lambek, Paul Lovejoy, Joseph Miller, Laura Murphy, Erik van Omering, Pamela Reynolds, Michaela Schäuble, Katharina Schramm, Marie Rodet, and Helena Wulff. Special thanks are due to my research assistant Njakoi John Bah, who helped me to gather all of the data for this article. I am grateful to the Diana, Princess of Wales Memorial Fund for providing research time for this article. 
from older ones. ${ }^{1}$ This is an unusual situation in West Africa, where the norm is for adults to tell folktales to children. For all we know, adult-to-child storytelling may have been the normal practice in the Grassfields in the past, but if it ever was, this practice has now passed into desuetude, and today adults look with mild scorn on folktales (fongaanen, dmgaanen pl.) and generally remain aloof during storytelling sessions. ${ }^{2}$ Storytelling in the Grassfields is therefore a child-structured form of play in Schwartzman's (1978) sense: it is an activity mediated by children without adult input. Prior to the introduction of schooling in the Grassfields, children used to be made to guard the crops against birds and monkeys, an activity that left them to their own devices in the fields for long periods of the day (Argenti 2001; see also Fortes 1938; Raum 1940). In some cases, children actually slept in small shelters that they built in the fields, and they would consequently stay away from their homes and adult supervision for days at a time. It was in this context, away from the censorious gaze of adults, that children's illicit masking activities developed (Argenti 2001). It may also be in this context that children were able to indulge in prolonged bouts of storytelling without fear of reproof by adults, in whose eyes children should be seen but not heard. Today, children no longer guard the fields, and they have therefore taken to telling their folktales at home.

In Oku, children now tell folktales at night around the hearth fire, usually after the evening meal has been prepared and eaten. A child will formally announce their desire to tell a folktale before starting by calling out "fongaanen-oo!," to which the other children present, if in the mood, respond "fongaanen!" and fall silent, thus marking their approbation and signaling their devoted attention. ${ }^{3}$ Once the first raconteur has told his or her folktale, many other children usually follow suit, making for protracted storytelling sessions of an hour or more. The duration of each story is marked out formally by the introductory call as well as by a closing refrain: "my tale has ended." This closing utterance is then often immediately followed by a moral, referred to literally as the "head" $(k \partial t u)$ of the folktale, which is recited by the teller.

1 Recordings of children recounting the folktales and songs presented in this article are available to download from Nicolas Argenti's webpage. In case of difficulty, contact the author directly.

${ }^{2}$ Silvia Forni (personal communication) confirms that it is also children who tell folktales in the Grassfields chiefdoms of Bamessing and Babesi, where she carried out research in the late 1990s. But see Todd (1979), who collected Pidgin versions of vernacular folktales told to her by adult informants from several chiefdoms living in Bamenda, the regional capital, in 1966. And see Mbunwe-Samba, who introduces his compendium of Grassfields folktales with the reminiscence of adults telling them by the fireside during his childhood (1998: iv). He also mentions, however, that the stories recorded for the volume were collected from school children in the 1970s (ibid.: v) in order to "rescue them from possible oblivion" (ibid.: iv), presumably because by then adults were no longer regularly telling them.

3 The term fongaanen simply means story or folktale. It is distinct from komficl: a historical myth told by adults. 
Within the house, children are usually silent unless spoken to and peripheral to the fire that burns in the hearth in the center of the room. Apart from babies and un-weaned toddlers, children are all assigned tasks in the preparation of food around the edge of the room in which the cooking goes on, and when it is time to eat they do so facing each other, or sometimes even facing the wall, rather than join the adults. In keeping with norms of respect for one's elders, they do not speak to adults but only to each other in hushed tones, and adults generally address them only to give them orders. When adults chat, it is amongst themselves. In contrast to children, adults occupy the center of the room, seated on stools around the fire, and complain bitterly when a child blocks their heat or their access to the cooking pot on the fire. Stepping over an adult's outstretched legs rather than passing behind him or her to get to the other side of the room is a mark of disrespect and impoliteness, thus forcing children to remain in the periphery of the room when moving round.

The practice of storytelling reverses these social relations. When children begin to tell folktales, they gravitate to the center of the room and the adults move to the periphery without complaining. Though they disapprove of idle banter and would silence children who were trying to converse with each other in their presence, adults allow children to tell folktales after the evening meal, and even fall silent when they begin to do so. ${ }^{4}$ Not only do they allow children to tell folktales, but they even sit impassively, or allow themselves jovial guffaws as children-normally so respectful in the presence of elders - revel in the violence and scatological obscenity with which the folktales abound. ${ }^{5}$ As a result, adults come to occupy the social and physical space of children for the duration of the fongaanen session: they become peripheral within the room and the soundscape alike. The children, on the other hand, suddenly become loud and self-assertive. Not only does the storyteller raise his or her voice, but all the others join in with their noisy approbation- "fongaanen!"- - as well as with the choruses they sing, ${ }^{6}$ and the lively chatting that goes on in the interludes between folktales. These folktales show a grasp of "adult" rhetorical skill, contrapuntal techniques (in the call-and-response songs that mimic those of adult songs and speeches), dramatization, and veiled references to witchcraft. ${ }^{7}$

4 See Heath's description of storytelling in a rural black community in the United States where children produced their own stories from the age of two, and were allowed by adults to interrupt their conversations (1983).

5 The grotesque aspect of Bantu folktales has been noted by Adam Kuper for the tales of Southern Africa (1987: 167-96).

6 This is what Harold Scheub calls "the poem in the story" (2002).

7 Watson-Gegeo and Boggs' young informants in Hawaii similarly provided stories up to forty minutes long complete with formal endings such as "Here finish now," and even "An it's five to nine, an gonna have da late news now" (1977). 


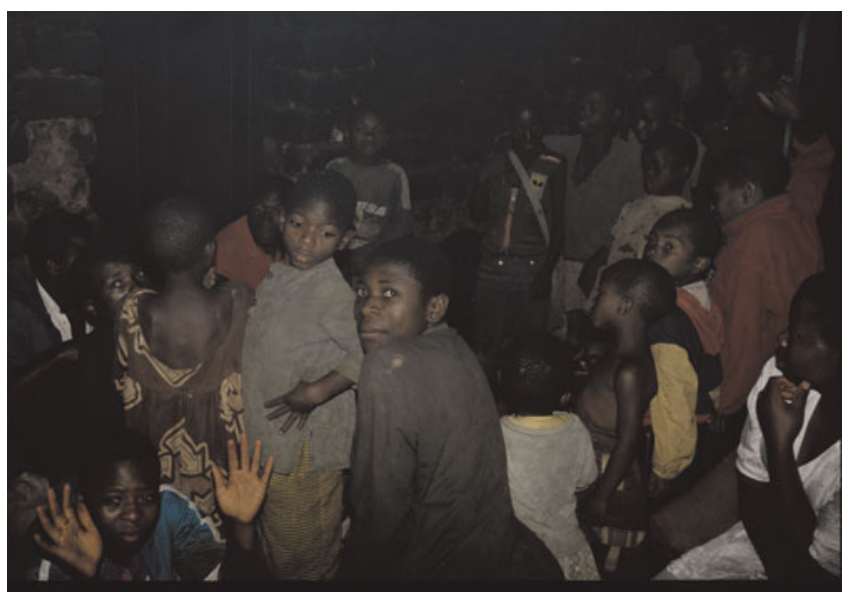

Figure 1 Fongaanen session, Mboke Jikijem, Oku, 2005. Photo N. Argenti.

One could analyze the interrelations between raconteurs and audience, the role reversals between children and adults, and the striking aura of carnivalesque jouissance occasioned by children's storytelling in Gluckman's (1963) terms, as a ritual of rebellion in which the subordinate members of a hierarchical society seek not to replace inequality with equality, gerontocracy with acephalous egalitarianism, but rather to take the place-however fleetingly - of those in authority. According to this interpretation, such momentary reversals serve ultimately not to transform the social order but, on the contrary, to buttress and to reproduce it. A focus on the content as well as the practice of story telling suggests, however, that this activity is more than a safety valve for pent up juvenile frustrations or an opportunity for momentary roll play to the children of the Grassfields.

That storytelling might seem to be divorced from social reality rather than representing a preparation for it might alternatively be seen in developmental or psychoanalytic terms, following Piaget or Freud, as an escape from reality by those who are disempowered and have little control over their immediate environment, let alone their social world. ${ }^{8}$ For Freud, and later Piaget, play is cathartic, representing a quasi-pathological escape from reality. In play as in storytelling, the child is engrossed in an imaginary world that is his or her own creation. This leads to the psychoanalytic position that children are divorced from reality, creating alternative realities as compensations for the lack of mastery that they can exercise in the "real" world.

\footnotetext{
${ }^{8}$ In Piaget's terms, such behavior is more "assimilative" than "accommodating" (1951). For a discussion of this issue, see Hellen Schwartzman's overview of theories of child play (1978).
} 
Just before Freud pronounced in his short essay, "Creative Writers and DayDreaming," that "the opposite of play is not what is serious, but what is real" (1959: 144), however, he also observed-perhaps paradoxically-that the playing child is seriously involved with the real world, and while we might not agree with the reality/fantasy dichotomy that Freud presupposes in the former claim, Freud's insight (ibid.: 143-44) that the playing child (or the storytelling child) creates worlds much as the author of fiction does might be very germane to our analysis. Folktales must be understood as fiction not in terms of the retreat from all things serious and "real" that many Victorians took the novel to be, but rather in terms of the very distillation of reality that is achieved in myth. Indeed, as Lévi-Strauss' entire oeuvre has demonstrated, myths focus on key social dilemmas that the surface chaos of everyday lived experience often renders opaque. Bettelheim (1976) proposes similarly that European folktales offer children access to aspects of psychic, if not social, reality not otherwise available, and quotes Schiller in The Piccolomini (iii, 4), "Deeper meaning resides in the fairy tales told to me in my childhood than in the truth that is taught by life" (in Bettelheim 1976: 5). With reference to Africa, Denise Paulme has argued, "A folktale, because it belongs to the domain of fiction and that little importance seems to be attached to it, permits one to address the gravest of questions" (1976: 11, my trans; see also Dundes 2007: 132). In this sense, we can see the child telling folktales as an author where it is not the author who is infantilized by the comparison, but rather the child who is shown to possess analytical and critical skills seldom afforded them.

Contra Gluckman, Freud, and Piaget, I therefore explore the folktales I recorded in Oku between 1992 and 2005 for their potential to enable children not to escape, but rather to address and express their lived experience of the world. And notwithstanding Lévi-Strauss' insights regarding myth, I do so not with a view to determining the folktales' internal significance as texts, nor the structures apparent in their relations to one another and to the supposed higher social truths to which these mythemes relate. Instead, I examine the open-ended potential for these folktales to address the personal anxieties, concerns, values, and aspirations of the individual children who tell and listen to them. As Oku children's lived experience has changed over time, so too what children bring to and take from the folktales they tell and participate in as listeners and chorus has also changed, and is liable to change again in the future. In other cases, in line with Austen's (1995) analysis of a Cameroonian Douala epic, and Gow's (2001) observations of Peruvian myth, it is clear that the folktales themselves are undergoing significant transformations in line with historical, political, and economic transformations in the region. ${ }^{9}$

\footnotetext{
9 Speaking of the epic folktale of Njeki la Njambè recounted in the Littoral region of Cameroon, Ralph Austen notes the perplexing elusiveness of the tale, which seems not to relate to the historical
} 
This paper focuses on children's contemporary experience of fosterage, but also examines the legacy of slavery to which fosterage is related, and which I argue many of the folktales originally addressed. In contemporary Oku about 30 percent of children are fostered at some point in their lives, and many of these children experience fosterage as a harrowing trial. For them, and for their younger siblings who look forward with apprehension to the fosterage that might be lying in wait for them, I suggest that the folktales they tell are poignant to them because so much of their subject matter can be understood from the point of view of the adventures and misadventures of fosterage, and indeed of the pawnship and slavery that preceded and coexisted with them into the twentieth century, and from which fosterage was often difficult to distinguish (Argenti 2007: 236-37; see Allman 1997; Bellagamba 2002; 2004; Falola and Lovejoy 1994; Fortes 1949; Goody 1982: 148-49; Grier 1992; Lallemand 1994; Renne 2005).

The folktales that Oku children tell and sing center on the dangers of the forest or the bush, and dwell on such subjects as witchcraft, cannibalism, and violence. A significant proportion of the folktales I recorded (fifteen of a total recorded corpus of forty) represent the farm, the bush, or the forest (and in particular streams within the forest) as scenes of danger and violence. In almost all of these folktales, the central characters are children, and it is they who come to grief in the untenanted wastes outside the safe haven of the home and village. The landscape outside of the confines of the village is not that of a natural cornucopia, but rather one of sinister desolation, where ordinary human beings are absent or only fleetingly present, replaced by cannibals and malefic spirit beings, and where life is best described in Hobbesian terms. The only beings able to thrive in this environment, save for the dead,

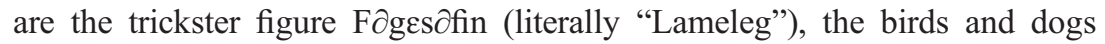
who stand in for benevolent spirits, and the chameleons, frogs, and insects that usually represent malefic ones (see Kuper 1987: 171). It is not for nothing that the Eblam Ebkwo expression refers to sinister or imponderable events as "things that have not come by the road"10; in other words, as having emerged straight from the forest or the bush.

And yet, in contrast to the idea of the home and hearth as a safe haven for the vulnerable child that this contrast between the civilized and the wild suggest, in a great many of the folktales the source of violence is surprisingly the mother. Of thirty-two folktales I recorded involving violence, the mother is the

context in which it emerged in any clear way (1995). The epic is silent on both trade and Europeans. Nevertheless, Austen's study reveals that the earlier folktale form was closely related to its historical context, and further that the story has ultimately been appropriated by contemporary bards, musicians, and audiences to their own sociopolitical context. See Vail and White (1991).

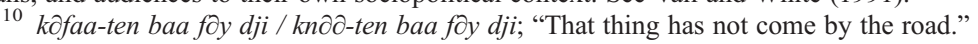


perpetrator in eighteen of them, and is described as neglecting her children, driving them away from home, or punishing them to excess, leading to the death of the child or children in the folktale. I have recorded only two folktales in which the mother plays a protective role vis-à-vis her children. This is a truly shocking representation of the mother in a kinship system in which the mother (though this is not a matrilineal society) is the most hallowed figure, as is the case throughout West and central Africa. ${ }^{11}$

The morals that are often made explicit at the ends of the folktales make them seem ethically conservative cautionary tales: warnings about what happens to the Icarus figures who fly too close to the sun, or to the greedy or selfish children and adults in many of the tales. But the lack of closure in the structure of many of the folktales suggests that the violence and insecurity are over-determined, and that the ambiguity of their ultimate lesson, their very indeterminacy, provide opportunities to appropriate, to usurp the original or adult-centric moral intent of a tale. This is especially the case in relation to the violence of the mother figures in the folktales, which the morals would feign to wrap in a cloak of respectability, but which nonetheless express deep ambivalence. As one child put it at the end of a folktale when I prompted him for the moral, "It's really hard to come up with a moral for this one." In other instances, the morals appear counterintuitive. In many cases, children tell folktales about naughty, wayward, or unlucky children to which they append morals that explicitly accuse the mother of cruelty or neglect. Folktales that adults consider to be cautionary tales for children, which would once ostensibly have saved them from slave raiders, are thus appropriated by child tellers, in part by means of the appendage of new morals, as accusations against parental figures who are turned into the immediate, tangible, source of danger and of moral culpability in the folktale. ${ }^{12}$

11 The Nigerian/Cameroonian singer-songwriter Prince Nico Mbarga's famous celebration of motherhood "Sweet Mother," quoted in the epigraph, gives the correct ideological position regarding the role of the mother, as do many other African popular hits, including Victor Démé of Burkina Faso's “Djabila" (2008), and Malian Habib Koité's "Wassiyé” (1998). Although one traces descent through one's father's lineage in the Grassfields ( $k \partial b a y)$, one always remains somewhat suspicious of one's father and of his lineage, within which one competes against one's siblings for eventual marriage or lineage headship. In contrast, although one has no legal or formal claims to descent

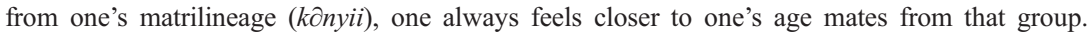
Denise Paulme (1976: 242, 266-67, 272-73) also notes the counterintuitive nature of these folktales in Africa, where stories involving the sale by a mother of her own children to a cannibal ogress are common despite, as she points out, the high social value placed on children.

12 As Newell (1997) has noted for Ghanaian popular narratives, the audience are co-creators of the plot, with individuals in different social positions identifying with different characters in the stories through whom they can apportion praise and blame. The meaning of the folktale therefore does not reside in the text only, but in the space the telling of the tale creates between the teller and the audience (see Barber 1997: 356-57). 


\section{LA MÈRE DÉVORANTE}

Many of the folktales relate to the abduction of a child. In one series of tales, a child named Kwako or Kunjoo who sets out for the farm alone is abducted by "bad spirits" (2myin 2mbee). The moral of these folktales admonishes children never to go out to the farm alone. Children note, however, that the mother in the tale is the one who lets the child go unprotected. While in the folktale of Kwako and the farm gods the child is not killed, in another series of folktales the kidnapper is not a spirit but a cannibal. In one such folktale a child and its mother are in the forest together, hurrying home to cross a river that becomes impassable "after two o'clock" each day. As they approach it, the child remembers she or he has left their walking stick behind and goes back for it. ${ }^{13}$ The child's mother does not go back with the child: she is in a hurry to cross the river and get safely home before it becomes impassable. As in so many Bantu folktales, the river becomes a dividing line between worlds, and as often happens, it signals the presence of a cannibal (see Kuper 1987: 19495; Shaw 2008). The river divides not only the civilized from the wild, but also the living from the dead, marking the fall of the child into the jaws of death on the one side, and the passage of the unencumbered mother back to safety on the other. ${ }^{14}$ Life and death here are marked out in the landscape as the two banks of the river, with the river operating as a liminal space facilitating passage between the forest (space of death), and the village (place of life), for a limited period each day. As I discuss below, however, this sylvan realm of death is not entirely sealed off from the world of the living, but rather represents a space into which children may come and go, just as spirit children (ron $\partial b a$ ), the most nemoral of all — the most closely associated with the forestare said to roam freely between the worlds of the living and the dead.

Soon enough, on the wrong side of the river, the child comes across a disembodied head that asks it a question in nonsense verse, sung by all the children listening to the folktale, to which the child answers (and all the children listening again join the chorus): "As I and my mother went to the farm and I forgot my stick and am going back to collect it — go down, come up, hit-on-the-head is still there." The child continues and comes across an arm, and the same question-and-answer chorus recurs. The same sequence is then engendered by the appearance of a thigh and various other body parts in succession. As the child walks on through this sinister landscape, it comes across "an old man who eats people" who invites the child home with him. He takes the child home, lays it on a bed, covers it with a blanket, and calls to his wives to prepare food, for he has caught meat. The wives come to see the catch, and one of them, taking pity, replaces the child with a log of wood and helps

13 Gender is not marked in Eblam Ebkwo pronouns.

14 The bank of a river is called its "mouth" (2btshuo). 
it to run away. The cannibal soon comes into the room and lands a blow on the bed with his cutlass, but only hits the log of wood. He gives chase, but the child has gone to hide in a house in which a burial is being celebrated (literally a "house of death"). The people there then kill the cannibal. Again, the explicit moral of this tale is not to let one's child go to the farm alone, but the implicit message, that mothers do sometimes abandon children to their fates on the wrong side of the river, is difficult to ignore.

In another folktale involving a cannibal, a girl named Mbo Gho is said to be an only child. One day a visitor comes to her parents' house, and when he is leaving, Mbo Gho accompanies him a little way along the road. Each time she is about to turn around and go home, the visitor asks her if she is going to leave him so soon, "as if he had not come to see her out of love?" As in the previous folktale, the visitor brings her all the way back to his house and lays her on a bed and tells others in the household to harvest bitter leaves (to make sauce), as he has caught an animal (nyam, meat/animal). This time, a frog assists the girl, replacing her with a banana trunk. ${ }^{15}$ They escape together, and on their way come across seven people. Each one sings the same song to Mbo Gho in succession, which the children in the storytelling session sing in a chorus. The folktale ends in a reversal in which one of the cannibal's fingers is amputated and put in the children's bitter leaf soup. (Since a finger is literally a

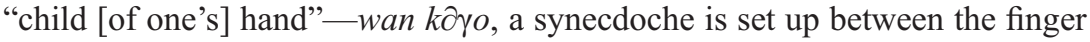
and the child.) From then on, whenever anyone eats bitter leaf soup, a little of the cannibal's finger is added to it. Again, the folktale ends well for the child, but the parents are shown to have been grossly negligent in the care of their child, if not complicit in its kidnap.

The neglect by the parental figure in the folktale is still more apparent in a third version of the cannibal folktale in which a traveling father and child are offered shelter for the night in a person's house. Their host on this occasion is "a very old man who had dried up and did nothing but eat people." The old man's son, however, warns the father and child that when they see his father approaching them in the night with his eyes shining, they should run away. Each time the cannibal father attempts to approach the guests, he is warned off by a song that the child guest sings for his or her father (the chorus sung by all the children), but the latter is in a deep sleep and only goes on snoring. The child replaces his body and his father's with banana stems, and the cannibal comes and cuts these with his cutlass in the night and has his wife cook them, but then drops dead as the smell of banana stems reaches him rather than that of human flesh. Once the cannibal has died, his wives slice off his penis and cook it. Again here, in contradiction to

15 Substitutions of this sort are common in West African folktales. See Denise Paulme's (1976: 242-76) analyses of variants of a folktale she names "The Children at the Ogress' House"; and Rattray (1930: 190-97). 
adult rationalizations for folktales, it is the parentified child who must save the father.

The landscape of the forest is a place in which the loyalty of one's parents is tested, as they may or may not come to their children's rescue in times of danger. Indeed, they may be the cause of the child's exposure to danger in the first place. For this very reason, however, the bush becomes a space in which a child can test its mettle, and from which, like the hunter or the warrior, it may return victorious and "adult." Both these elements-parental neglect and child wanderlust - are apparent in "Sometin' don bite me." In this folktale, as related by Mambe in Eblam Ebkwo but with the chorus in Pidgin:

A person once had a child, and there was a stream. [A group of] children went to play in that stream, and a snake bit the child. The child came home, sat with its mother, and sang to her:

[Chorus (original in Pidgin)]

Mami wash me, wash me, wash me,

Mami wash me sometin' don bite me [something has bitten me].

And she further sang:

[Chorus]

Mami rub me, rub me, rub me,

Mami rub me sometin' don bite me.

Mami wear my clothes, wear my clothes, wear my clothes, ${ }^{16}$

Mami wear my clothes sometin' don bite me.

Mami wear my socks, wear my socks, wear my socks,

Mami wear my socks sometin' don bite me.

Mami wear my shoes, wear my shoes, wear my shoes,

Mami wear my shoes sometin' don bite me.

Mami wear my cap, wear my cap, wear my cap,

Mami wear my cap, sometin' don bite me.

Mami dimagra, dimagra, dimagra,

Mami dimagra, sometin' don bite me. ${ }^{17}$

Mami goodbye, goodbye, goodbye,

Mami goodbye sometin' don bite me.

My tale has ended. The moral of the tale is that....

Unable to come up with a moral for the folktale, Mambe ended it abruptly there. And indeed, it would be a challenge to come up with a moral for a tale with no redemptive ending such as this. The folktale appears to offer only the tragedy of a slow death that is all the more heart wrenching for the fact that the mother appears to be playing a protective, nurturing role-holding her

16 To "wear" in Pidgin = to put on. The child is asking its mother to dress it.

17 Dimagra, sometimes pronounced dimagre, has no meaning in Eblam Ebkwo, and is of obscure origin. It may have come into Pidgin from the Portuguese diminuir, or the Italian dimagrire: to become impoverished, to diminish, dwindle, waste away, or grow thin. It is equally likely, however, to be of local origin since these tales when told in Pidgin have often been translated from other local languages, and often retain the songs in the original language for the purpose of rhyming and cadence even after their meaning is unknown to the teller (Todd 1979: 12). 
child on her lap and dressing it - but is doing so too late, inappropriately, and with a perversion of true nurture and care to which both mother and child seem to be resigned. Indeed, in asking for conventional care at such a critical moment, the child appears to accept that its mother has no real protection to offer.

Another version of the folktale is the same bar for an alternative opening scene in which the child is playing in the river with a European ( $k \partial m b a \eta$ "red person"). The European figure kicks a ball from one side of the river; the child kicks it back from the other side, and as s/he does so, wounds her foot. The child then comes home and sings the song to their mother. In this version, the snake is effectively replaced by the exotic but no less sinister white person who is the cause - albeit an apparently indirect one - of its injury and ensuing death. In Oku, riverine incarnations of white men and women, snakes or leopards are also known as "Mother [of the] River" or "Mother [of the] Water" (No Djio). Known as mami wata or papi wata figures on the coast, these selfish and seductive spirits are thought to lure devotees to their death by making ever more impossible demands on themdemands for Western luxury goods that have made of mami wata cults an apt metaphor for the effects on West Africa of extractive global economies, rentier politics, and commodity fetishism. ${ }^{18}$

Again here, the river marks a passage from the world of the living into that of the dead, marking the site of sylvan dangers lurking in wait for the child; in this case a snake, or a white man, each portrayed as interchangeable amphibian predators. The theme of the neglectful mother crops up again as well, this time all the more poignantly because the child returns to its mother for help. The doomed child seems to have a premonition, however, that the mother will do nothing to save it, save to prepare it for the journey to the other world on which $\mathrm{s} / \mathrm{he}$ is about to embark. Rather than asking for help, the child asks only for a ritual preparation for its departure, couched very much in terms of a departure for a journey. The folktale is trenchant because it recasts the ordinary quotidian rituals of motherly care in the perverse role of preparation of a corpse for burial. And indeed, the mother, who is voiceless and plays an entirely passive role in the tale, prepares her child for death with all the solemnity of dressing it for school in the morning. The feelings of the mother remain totally unexplored in the song, with the result that she is a blank screen without depth - a two-dimensional figure apparently devoid of human empathy or emotional background. ${ }^{19}$

18 See Bonhomme n.d.; Drewal 1988; 2008; Frank 1995; Gore and Nevadomsky 1997; McCarthy Brown 2001: 223-24; Masquelier 1992; Ogrizek 1981-1982; Salmons 1977; Shaw 2008.

19 Auerbach (1968), in his magisterial overview of Western literature from antiquity to modernity, has noted this lack of depth in characters in the Greek epics. Homer, for instance, "knows no background" (ibid.: 4), his epic poetry provides "never a glimpse of unplumbed depths" (ibid.: 7). 
And yet, another reading of these two tales might suggest a motive for the child to enter the river and depart from this world: Karen McCarthy Brown has recorded Haitian versions of the mami wata tale (there known as Lasyrennthe mermaid) in which those who are lured into the water (often impoverished female children) later return empowered with the skills of a healer (2001: 22324). In these versions of the folktale, the children are taken to Ginen (Africa), returned to their ancestral homeland to acquire the powers they had lost through the violence of their original uprooting. And yet, when they return from beneath the sea they are said to be "whiter," with fairer complexions and straightened hair (ibid.: 257). This reading of the mami wata tale suggests that an entirely miserabilist reading of the Oku version may be misplaced. Here too, the child and its mother may be complicit in the departure to the land of the white man - a realm of slavery, perhaps, but also of spiritual or material enrichment. It may be a realm of death, but not necessarily one from which there is no return. In this sense, the folktale of the snake/white man bears a strong connection not only to past slavery, ${ }^{20}$ but also to the current situation regarding fosterage, in which the mother (and to some extent the child) take a calculated risk that the child will return safely, and that it will return with gifts. ${ }^{21}$

In another Oku version of the tale, the siren does not live in the sea, but in a river:

There once was a beautiful princess for whom her father the fon [king] would accept no man's offer of marriage. One day, after the fon had again turned down many suitors, the River Mother set out for the palace. On the way, s/he [the spirit is asexual; see below] borrowed clothes, shoes, a cap, and a car. When the girl saw the car, she accepted the River Mother as her husband. ${ }^{22}$ As they make their way back to the river together, people retrieve their clothes and the car from the River Mother one by one, so s/he reaches the riverbank naked, and grabs the princess and dives in with her. [The River Mother's dwelling beneath the river is an exotic, modern hotel-like building in which the rooms are numbered.] S/he puts the princess in room 20 , and goes to sleep in room 15. The River Mother does nothing but sleep, from Thursday to Thursday.

His heroic characters, such as Oedipus, memorably "wake every morning as if it were the first day of their lives" (ibid.: 12). But while this trait is a generic characteristic of Greek myths, it applies primarily to adults or victimizers in Grassfields folktales, while children are described more empathetically.

${ }^{20}$ Fagunwa's (1982) Yoruba folktale Forest of a Thousand Demons, translated by Wole Soyinka, includes a predatory "man ... with fins cover[ing] his body so that it had the appearance of a fish" (1982: 38, in Wehrs 2008: 86). Wehrs underlines the clear associations of this mami wata figure with the ocean, cowry shells, and the power of the Atlantic slave trade.

21 A Pidgin version of the tale recorded by Loreto Todd (1979: 160-69) in the town of Bamenda in 1966 has a girl marrying a "Papa Wata" and "playing" with him on the shore all day in return for boat loads of fish with which she feeds her whole village.

22 The teller first identifies the suitor as a mami wata, then calls it No jio ("Mother River/Water"). Although she first identifies the father as the cause of the princess' prolonged spinsterhood, she then suggests it is the princess who is seduced by the car rather than her father. Ultimately, however, it is the fon who is shown to have been seduced by the wealth of the mami wata. 
Meanwhile, the neglected princess withers away till she finally finds a bottle in her room into which she places a message. It is found by her brother who shows it to her father the fon.

In a second part of the folktale, the fon assembles a crack team to free his daughter, consisting of a lookout, a sharpshooter, a thief, a driver, and a car mechanic. Each in turn plays his role in freeing the princess from the clutches of the River Mother, but no sooner is the princess freed than each one demands her hand from the fon as their recompense. The fon then announces that he will give his daughter to the first of them who brings him gifts as a brideprice. The thief goes into the nearest house, steals all he can lay his hands on and brings it to the fon. The delighted fon then unhesitatingly gives his daughter to the thief. $^{23}$

In this tale, the selfishness and materialism of the fon lead to the demise of his daughter the princess not once, but twice. In the first instance, the fon is in thrall to a mami wata spirit who appears to be fantastically wealthy, while in the second instance he again puts aside any scruples regarding the moral qualities of the suitor to give her to a thief who offers him a stolen brideprice. Looking back from the vantage point of this tale to the two versions of "Sometin' don bite me," it is clear that the snake and the white man playing ball by the river bank and luring children to their death are also mami wata figures. In painted images of mami wata figures, this piscine deity is depicted interchangeably as a white woman or as a snake, while in the landlocked Grassfields snakes are reputed to be chthonian figures, able to burrow like moles in the realm of the dead beneath the ground. As on the coast, it is with Western consumer goods that the river deities in these hinterland tales possess and seduce their victimsa football in one folktale, a car, fine clothes, and a hotel in another. The underwater landscape into which the princess is drawn by the mami wata figure in this tale is a luxurious but a curiously inhuman one. The princess is imprisoned in a many-roomed palace, or hotel with numbered rooms, but is wasting away from hunger (as is the young bride starved by her human husband in a folktale I relate below). Her wealthy "husband," meanwhile, is in fact a naked female beggar whose inhuman identity is underlined by her indeterminate gender and asexuality $-\mathrm{s}$ /he has no human appetites, no desire for sexual intimacy or for commensality, but sleeps all week long (a Western seven-day week that spans from "Thursday to Thursday" rather than the local eight-day week). While the fon in this tale lives in thrall to the luxury consumer goods of Western modernity (indeed he lives in a mirage created by the devilish mami wata), his daughter the princess lives in the flip side of commodity fetishism - trapped in the landscape of poverty, alienation, hunger, and exile that is the ultimate consequence of her father's materialism.

23 Cf. the Yoruba tale "Antere, the child of the goddess of the river" recorded by Amos Tutuola (1986: 15-20). In this version of the story, the king fails to retrieve the girl from the river goddess. 
The mami wata cults and stories of Africa are a modern phenomenon, tracing the imbrication of African societies into global trade networks in the form of extractive economies that find their apogee in the transatlantic slave trade. It is fitting, therefore, that contemporary versions of mami wata tales transpose the exemplar of the treacherous deity from the mermaids that once adorned the prows of the slave ships (Drewal 1988) to a seductive woman who now flies a plane. In this version of the mami wata tale, the spirit lives not underwater, but flies in the air:

A person once flew to an "aeroplane field", bore a child and abandoned it [lit. "threw it away"] there. Someone came along and found the child and brought it up. When the child had grown up, though, its [adoptive] father again started to hate it. As he went out early one morning, the child packed its bags and left. On the way, the child saw a person's door and sang:

$\mathrm{N} \partial$ lu nde nowom-be? Who's my mother?

Bis. $^{24}$

And the child's mother came out and sang:

No lu me no vie. It's me your mother.

Bis.

And the child again sang:

$W \varepsilon$ no bii yai $m \varepsilon$ ? Where did you bear me?

Bis.

And the child's mother again sang:

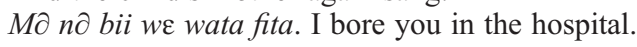

Bis.

As she was singing, the child saw that the woman was not her mother [because the woman claimed to have given birth to her in a hospital rather than on the airport runway], and she moved on. She again went to the door of another house and sang:

No lu nde no wom-be? Who's my mother?

Bis.

Another woman came out of the house and again sang:

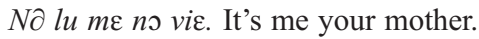

Bis.

And the child again sang:

We no bii yai me? Where did you bear me?

Bis.

And the woman again answered:

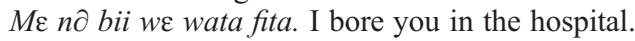

She saw [the woman] was not her mother, and again she passed on. She then saw a very fine house, all painted [lotz, paint-painten]. So she stood at the door of that house-and the house was even of several stories! [naa, no nda-ten lu up-storey-building!] and she sang:

No lu nde no wom-be? Who's my mother?

Bis.

And a woman came out of that house - [ [she was] beautiful! - and she came and sang:

No lu me no vie. It's me your mother.

Bis.

${ }^{24}$ Bis is the instruction in music to repeat a verse in a song. 


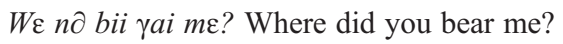

Bis.

And the woman then answered:

Me nə bii we aeroplane field! I bore you on the airport runway!

The child ran to the woman and hugged her: She was her mother!

Again in this instance the woman is no ordinary person, but one who flies in the night, arriving from another country. When her abandoned daughter finally finds her, she is living in a luxurious "up-storey building"- - a type of structure only very rarely seen by the majority of the children telling this tale, excepting those who have been fostered to urban households. The woman's beauty and wealth are very pronounced in relation to the other potential mothers in the song, but they are clearly of exogenous origin. There are no "painted houses" or "up-storey buildings" in the village of Mboke-Jikijem in which the children telling this folktale live. The tale has a happy ending of sorts, but it is ambiguous: its ending is simply the resolution of the dreadful act of abandonment that opens the action. And this mother, though desirable, is ultimately revealed to be a mami wata figure or a witch, for only a witch could possess such unaccountable wealth, especially a single woman. The very same wealth that makes her such an attractive mother figure to the children telling the tale, then, is also the proof of her perfidiousness, suggesting that anything might happen to the child now that it has found her again. Just as adult devotees are helplessly seduced by the modern consumer goods that highlight or even constitute the sensuality of the perfidious mami wata figures they worship, so too the absence of any proper sense of love and care for her child by the mother in this tale is masked by the enchanting wealth she is able to display.

In many of the tales mentioned above, parental figures play roles that are remarkable for their ambiguity; rather than representing figures of nurture and protection (as they do in overt discourse), they stand by helplessly or indifferently as their children depart, come to harm, or die. In all cases the tragic magnetism of misadventure is recorded as a movement from the safe haven of the home to the untenanted wastes of the forest and the murky depths of rivers. Both are landscapes not only of the land of the dead and of malevolent spirits for the unfortunate children in the tales, but also of the unhomeliness (Bhabha 1994) and alienation of modernity. And the nefarious role played by the mother vis-à-vis her child is brought out all the more unambiguously in another series of folktales in which the neglectful and abusive character of the mother is made explicit.

In one folktale, virtually the first thing we are told about a girl called Celine Kodjiayimey (lit. "that will not end") is that "her mother and father did not like her at all." This hatred was apparently unprovoked, since Celine was "very obedient to her mother and father." Despite Celine's obedience, we are told that her mother takes her out of school so that she can keep her working at home. One 
day, in an apparently unprovoked act of aggression, Celine's mother tells her to grind chili pepper, then leaves the hut and locks the door behind her, leaving her daughter to suffocate. The girl is saved by her grandmother who hears her crying and takes pity on her. From this point, Celine's grandmother continues to protect her from her mother. After some years, a suitor comes and asks for her in marriage. He pays the full brideprice - a highly unusual arrangement that frees him of any debt to his new in-laws - and takes Celine away with him. But as he has paid the full brideprice, he knows that he can treat her as he pleases. He begins to treat her so badly that she starts loosing weight. Even though she becomes pregnant, the man still hates her. Once she gives birth to her child, her husband continues to neglect her, but an old school friend supports her. Celine thinks of going back to her compound, but her husband prevents her from doing so, "because he had bought her just as one buys a commodity." Later in the folktale, however, this very fact instigates a reversal of fortune for Celine who, as she returns home, becomes a successful market trader, and gets on well again with her mother. The spiteful mother does love her daughter in the end, then, but only once the latter becomes a wealthy trader so successful "that her parents did not even know she was there" (because she ate none of their food).

Although apparently a cautionary tale about the pitfalls of marriage, this folktale is at least as much about slavery and fosterage. The "husband" of the tale is a thinly disguised impostor, a kidnapper of the sort that used to abound in the Grassfields from the seventeenth to the twentieth centuries, thriving by seducing children and adolescents away from the safety of their homes on a pretence in order to abduct and sell them, either into the domestic or the transatlantic slave trades (Argenti 2007; Warnier 1995). ${ }^{25}$ The tale recasts the trickery and seduction deployed by these kidnappers in terms of a perversion of courtship. The role of the grandmother in the tale also alludes to fosterage; the maternal grandmother is seen as a particularly affectionate kin member and an ideal foster parent in the Grassfields as in much of West Africa (see Alber 2004; Notermans 2008: 361). In the tale, the ideal caring role of the grandmother is usurped by the premature marriage of the girl to the thinly veiled slave trader. If the grandmother is the ideal foster parent in a system of mutual care and nurture, the flawed marriage of the tale indexes the transformation in the course of the eighteenth and nineteenth centuries of a local,

\footnotetext{
25 As late as 1927 a court case arose involving the enslavement of a young Oku boy by the name of Mba and his sale into slavery in the neighboring chiefdom of Nso'. The boy had been sent into foster care by his father, but the foster father handed him over to others who traded him, called him nkwa (slave), and kept him tied to the house (Buea Archives 1927). Another case two years later concerned a young girl from the chiefdom of Age abducted from her father's house and sold for three Dane guns, four bottles of gun powder, two goats, a cutlass, and a bundle of tobacco (Buea Archives 1929). For each case that came to court, we can only surmise that many others were never detected.
} 
kin-based fosterage system into an increasingly amoral trade marked by the dangers of monetization, extractive long-distance trade networks, and rentier economies.

In another tale a child goes to the bush with its mother and on the way home falls and breaks its leg. The child is saved by other women, taken to hospital, then returns home to convalesce with its mother. One morning, however, the mother wakes to find her child has died. The rest of the folktale describes the mother's jealousy as she sees other mothers with children in church. The moral of the folktale as told by a very young narrator is "that the mother threw away her child on the way home." He was corrected by an older child, who said the moral was that the mother should not have left the child on its own on her way home from the farm. In many cases, the folktale the child tells is explicit regarding parental neglect but ends with a moral that euphemizes the preceding lapsus. This telling reverses that principle, with the folktale being rather ambiguous regarding the culpability of the mother, but the child making explicit in the moral that it relates to a maternal neglect that it dare not speak. The tale thus again challenges the adult rationalization that folktales serve to admonish children to stay with their parents. In this case, it is the children telling the tale who admonish mothers not to abandon their children. ${ }^{26}$

Another tale, which appropriates the Western fairytale of the three little pigs, replacing the pigs with goats, makes the mother's hatred for her child more explicit. Again, the reason why the three little goats need to leave home to build their own houses is because "their mother hated them." When a young child told this folktale, she added the moral that "people should not hate their children." Yet another tale that propounds this theme is structured as a counting game. The folktale consists of "a person who had ten children and hated them." His or her neglect of the children leads to their deaths, which gives the opportunity to sing backwards from ten to zero. The child who initiated this song added a moral to the end emphasizing the culpability of the mother for the death of her children: "When you have your children, no matter what the child does to you, do not speak ill of it."

The list of abuses goes on with each new folktale told. One very short tale simply tells of a mother who sends her child to fetch water, then beats her and drives her away from home for breaking her calabash of water as it falls from her head on her way back from the river. L, one of the children in the group telling this story, told me on another occasion of being punished by her foster father for the same offence: "The man beat me when I went to fetch water and broke the water container and did not tell him. That is the

\footnotetext{
26 Denise Paulme (1976: 10) has noted a similar appropriation of a folktale by Dogon youths. A folktale she recorded in 1935 ended with the moral that "one must heed one's elders." Thirty years later, Geneviève Calame-Griaule recorded the same tale with its meaning inverted, the son now coming to the rescue of the father.
} 
only time he ever beat me ... but his children were fond of beating me.... Sometimes when I disagreed with one of them, they would try to cut me with a cutlass" (19 June 2005).

Another tale tells of a mother who neglects one child in favor of her two favorites, only to have the two favorites eaten by a leopard. As told by one child, the moral of the folktale is "If you have children do not hate any of them." The reversals in this folktale, according to which characters are given instructions by animals or spirits to take counterintuitive courses of action and thwart their commonsense impulses, recurs in many Grassfields tales, and always serves to differentiate a wise from a greedy child; the wise one following the spirits' instructions, and the greedy one ignoring them and being punished for his or her gluttony. Again, however, the adult cautionary message aimed at children is reversed by the child teller of the tale, who ultimately makes of it a reflection on adult moral conduct in relation to children.

A final tale again presents the mother's mal-socialized or uncultivated behavior as placing her children in danger and ultimately causing harm to the less astute of the two. The tale is a trickster tale about Tuk and his friends Emgie, Jel, and Eynkey.

Tuk invites his three friends to help him clear his farm. During the clearing, Eynkey (a female rat) says she is going to drink water, but then eats all the food and defecates in the basket, then eats the soup as well and urinates in the clay pot it was in. When Tuk discovers what has happened, he digs a pit, and orders all of them to jump over it. Whoever drops into it will be shown to be the culprit. Tuk jumps first, and as he does so sings:

It's me, the child of the house of Tuk-a, Tuk-a,

Do not steal, if I steal Foges $\partial f i n !^{27}$

Tuk crosses successfully to the other side. Jel then sings:

It's me the child of the house of Jel-a, Jel-a,

Do not steal, if I steal Fogesofin!

Jel gets across the pit successfully. Eynkey then sings:

It's me the child of the House of Eynkey-a, Eynkey-a,

Do not steal, if I steal Fogesofin!

Eynkey falls into the pit and is shown to be the culprit. The others bury her on the spot and go home. As Tuk is coming into the village, Eynkey's children ask him where their mother is. He replies that their mother is the last in line. They get the same reply from everyone they ask. Finally, they return home feeling sad. Their mother, however, does return home, and instructs them all to weep for her, as if she had died. The children each sing in turn:

My mother and my father died before me, felala, felulu, ${ }^{28}$

Aeee, lies! Felala, felulu.

And the third child adds these verses to the song:

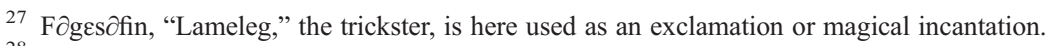

28 Felala, felulu is a nonsense verse. 
Could it be that she went out and was beaten to death, felala, felulu?

Why did you set out and eat the farm food, felala, felulu?

Aeee, lies! Felala, felulu.

The other children take offence at this accusation, and beat their younger sister and chase her away from home.

The girl then asks the way of a passer by, who tells her that when she comes to a fork in the road, she will see one clean and one dirty road, and she must take the dirty road. She takes the dirty road, and has beautiful children. The child returns home, where she hides in the ceiling rafters with her children. She is found by her mother, who rejoices and welcomes her home. Seeing this, the second-born child decides to make herself hated so that she too can go and find her children. She asks the way of the same person [spirit], but ignores the spirit's advice and chooses the clean road. She then has caterpillars, snakes, and chameleons for children. She goes home and hides in the ceiling, but her mother discovers her there, finds her children inside a basket, brings them down the ladder and kills them all.

In this folktale it is the mother's initial act of gluttony that leads to the banishment of her third child, and it is the mother who kills her second child's children. Once again, the children in this tale survive by their wits in the hostile world into which they are banished by the actions of their mother, and only the wisest manage to return successfully to the maternal home, and even then at the risk of having their children killed by their mother. The hostile wilderness into which the children venture is also a place of potential wealth and fertility, however, from which the children can obtain their offspring and return home as respected adults. In the tale of the abusive husband it is the daughter's union to a slave trader that provides her with the children by means of which she can return home and be loved by her mother. In this folktale, the abusive husband is replaced by the bush as an equally hostile realm in which the child must live by her wits to obtain the offspring that will allow her to return home as an adult. It is not only children, however, but also other forms of wealth that children seek in the realm of the spirits. Fosterage, for all its dangers, is also seen as a potential source of enrichment for the child who can survive its pitfalls. ${ }^{29}$

FREE MARKET FOSTERAGE

Insofar as it is associated with the slave trade, the forest that surmounts the peaks of the mountainous landscape of the Grassfields exists as a space of memory (Argenti 2007). In myth, ritual, and masked performance, the forest is the liminal site of the disappearance of individuals from the chiefdom

${ }^{29}$ Bledsoe (1990: 77) notes that fosterage is seen as a means of acquiring esoteric knowledge in faraway places, nowadays imagined as urban centres. "Individuals who travel to, or learn about, faraway lands have privileged access to powerful, mysterious knowledge." 
toward the plantations and slave ships on the coast. In a more immediate sense, the forest marks a disputed borderland between chiefdoms, a space that is left deliberately unpopulated because it is prone to attacks - in the past by opportunist slave catchers, and now by belligerents in violent border disputes (Argenti 2005). The forest thus not only was a great bestial mouth that devoured slaves (Argenti 2001; 2007), but also remains a space of violence in which men, women, and children may confront wild animals and hostile parties from neighboring chiefdoms. As these folktales show, however, it was not only the forests that were seen in this sinister light, but the bush or farm as well. ${ }^{30}$ This is in keeping with the historical fact that people, especially children, were often abducted from their farms by small parties of raiders in the period of the slave trade (Warnier 1985: 138, 271; 1995; Chilver 1961; 1964; Masquelier 1978: 62), making the moral of the tales espoused by adults - not to let one's children go to the farm alone-sound advice.

But in times of hardship, children of the Grassfields could be abducted in a more sinister manner than by means of kidnap by marauding strangers - their parents might sell them. Warnier $(1995 ; 2007$ : 198) has depicted the role of a family member - usually a male elder whom he terms the "Judas," but at times also the biological parents - in this illicit trade in one's own flesh. Collective memories of the Judas clearly inform the ubiquitous metaphor of cannibalism in the folktales. ${ }^{31}$ In Oku, memories of the perfidious, predatory parent are still alive today, though they are expressed in veiled terms, inter alia as funereal elegies (Argenti 2007: 232-33). Just as children were prone to enslavement in the past, so too they play a prominent role in the tales that they tell each other of the unalloyed greed of the slave trade that once made of parents potential predators.

The cannibal is an embodiment of the slave trade, and folktales involving cannibals also make veiled references to the culpability of the parents in delivering their children to the cannibal/slave trader. In Ashanti versions of the cannibal tale referred to by Denise Paulme (1976: 258), a mother asks the king to sell her children to Death [the cannibal ogress of other versions] in return for objects of gold. Paulme sees in the image of the king a Freudian symbol of the father, but misses the reference to the slave trade. When the child manages to escape from the clutches of Death, Death makes a bargain with him, asking him to send his future houseguests to her in compensation, in return for which she will send him the gifts she receives from her "worshippers." In this monetized personification of Death as a trader in human beings, the escaped child turns from slave to slave trader by means of his ruse.

\footnotetext{
30 Indeed, in Eblam Ebkwo, while tilled farmland under cultivation is referred to distinctly as ilim, bush or fallow land bush or fallow land ( $\partial b k w a k)$ and forest $(k \partial k o s)$ are both seen as desolate and potentially hostile places.

${ }_{31}$ See Nwokeji and Eltis 2002.
} 
In Tutuola's (1978 [1954]) picaresque tale My Life in the Bush of Ghosts, based upon Yoruba folktales, the child escapes into a forest where a multitude of ghosts fight to take him as their "servant." Just as in the Oku cannibal tale mentioned above, all of these ghosts are described as missing body parts (1978: 27). Murphy (2007) points out the manner in which the work is set ambiguously in an ostensible present that is everywhere intruded upon by a resurgent past of "slave-wars which were very common in every town and village" (Tutuola 1978: 17). In this collapsed past/present, the realm of the bush encrypts unspoken memories of the violence of the slave trade, and contemporary "ghosts" embody the haunting presence in the landscape of marauding slave traders. In an earlier work of Tutuola's, The Palm-Wine Drinkard (2004 [1952]), the "drinkard" ventures into the bush to find his deceased palmwine tapper. Again, the time period is one in which "we did not know any other money except COWRIES" (2004: 7), but in which people are simultaneously bought and sold for British pounds. ${ }^{32}$ An early episode of the novel parallels one of the Oku cannibal tales recounted above, but replaces the figure of the cannibal with a personification of Death (2004: 13-14). Making his escape from Death, the drinkard finds himself in another tale familiar to the Oku children: he comes to a village in which the chief's daughter has been seduced by a spirit disguised as a "complete gentleman." Like the mami wata spirit of the Oku tale, no sooner has this apparition lured her into the bush than he begins to return his clothes, and then even his body parts, to other spirits from whom he has rented them, paying each their fee. He then enslaves the girl he has seduced (2004: 16-31). The complete gentleman's shedding of clothes is thus linked to the dismemberment of the body in the cannibal tales Tutuola relates. Once again memories of slavery are expressed in terms of monetized trade, Western commodities, and physical dismemberment.

While it is clear that the reality of slave trading might originally have lent the landscape of the Grassfields its sinister connotations for children, this does not explain why memories of slavery and tropes of a predatory Western consumerist modernity should remain a charged issue for children today. For this, one needs to turn to an examination of the relationship between slavery and fosterage. The end of slavery was often celebrated prematurely by colonial forces in Cameroon (Rudin 1938), with litigation arising from disputes about slaves and the actual trade in slaves going on into the 1930s (Buell 1928, v. 2: 314; Chilver 1961: 237; Chëm-Langhëë 1995: 184-87; Chëm-Langhëë and Fomin 1995: 194-99; Ruel 1969: 13, 166-68). As the trade in slaves gradually declined, suffering what Lovejoy and Hogendorn (1993) has termed a "slow death," it was of necessity replaced with other forms of labor, much of it also bonded and more or less exploitative, and dependent upon child labor in the form of

\footnotetext{
32 Cowries were the sine qua non of the slave trade in West Africa. See Argenti 2007: 132-35; Falola and Adebayo 2000; Hogendorn and Johnson 1986: 110; and Warnier 1985.
} 
pawnship and fosterage (Falola and Lovejoy 1994; Lovejoy and Falola 2003; Miers and Roberts 1988; Rodet 2009).

While Heidi Verhoef (2005) has published a sanguine assessment of children's fosterage experiences in the Grassfields which takes at face value parents' assurances that children themselves choose when and to whom to be fostered, Catrien Notermans' 2008 work on fosterage in Eastern Cameroon cautions that such positive assessments of the benefits of fosterage tend to focus on dominant adult discourses at the expense of delving into the lived experience of fostered children themselves, which is very often at odds with adults' perspectives. My own data from Oku similarly shows that in many cases fosterage (referred to simply as elond, meaning "to request," and "to lend" but also, significantly, "to give")-which is now often arranged through middlemen - operates as a euphemism for various forms of child labor, and that children's experiences in their foster families are often of a difficult if not harrowing time spent away from the home. L, a foster child I knew, once also produced the dominant ideology that it was she - at the age of three-who had decided herself that she wanted to accompany one of her father's business acquaintances home to the chiefdom of Nso', crying until her father allowed her to go. Her mother, who was present at the interview, scoffed at this idea:

\section{L: I was weeping so they asked me to come along.}

Mother: She was still childish and this explains why the day they had to go she was weeping to stay. She was only fooled into leaving.

In the past in Oku, it was often a favored male child, chosen for succession, that the compound head entrusted to the care of others. Fosterage served the dual purpose of providing an education in leadership for the child and of protecting him from witchcraft attacks by jealous siblings. Several other longstanding forms of fosterage also existed, and persist, in Oku. One, known as Kentchok ("chosen, picked out"), is a form of delayed brideprice involving the gift of the child rather than a fosterage agreement. The expression wan we ebam ("child from behind") refers to a child sent back to its mother's parents in the event that it was born out of wedlock. (The trickster tale above, about Tuk and Eynkey, recounts this form of fosterage). Another local form of fosterage is that of grandchildren by elderly couples. As Alber (2004) has outlined for northern Benin, this form of fosterage, though once common and socially sanctioned, is increasingly unpopular with parents in Oku who prefer to provide their children with opportunities offered by residence in urban centers. But in moving foster children from local care by grandparents to care by more distant kin and to non-kin abroad, the likelihood of exploitation and abuse increases. This is so in the first place because foster parents in urban centers are salaried couples with children who seek a foster child to baby-sit and to perform domestic chores, and secondly because the 
distance from home ensures a level of unaccountability that would not be possible within the chiefdom itself.

Fosterage is thus noted by many of my informants for the suffering caused by being exiled from one's language environment and separated from one's parents, siblings, and friends. It is experienced by many children as a time in which one is the subject of teasing and abuse by the biological children in the adoptive household, and in which one is often neglected, exploited, and subject to physical violence at the hands of one's foster parents. At the same time, however, just as in the folktales, many children emphasized the advantages their fosterage had afforded them in the same breath as they described the abuse and exploitation to which they had been subjected. L, for instance, quoted above as crying to go to stay with her father's business partner, goes on to describe how she was discriminated against by the wives in the compound and their children, who would beat her and even attacked her with a cutlass. When she had forgotten her native Eblam Ebkwo, but still struggled to speak the local Lam Nso', she was told by one of the wives that she had been "brought to town from the bush to be tamed." But L also emphasized that she learnt from her foster parents to be respectful ( $s \partial y \partial n g v \partial m l e)$, as well as the trade of tailoring, and that she would readily foster out one of her own children.

L's half-sister C was fostered three times, twice to her father's kin, and once to a medical doctor from Nso'. It was the non-native foster father, Dr. N, whom she liked most both for his generosity to her and for his kindness. The other two sets of foster parents treated her harshly, making her do all the household chores and feeding her less than their own children. "When I was punished," C recalls, "I felt bad and thought that my parents would not have beaten me as much." These foster parents also accused her of stealing from them - a standard ploy used to exonerate foster parents from the obligation to make gifts to a foster child on their return home. But when $\mathrm{C}$ remembers the goats that Dr. $\mathrm{N}$ gave to her as her leaving present and the money he used to send to her father and mother, as well as the towns she got to see, she is pleased to have been fostered: "On my part I benefited a lot as a result of my stay with foster parents. I was able to do a lot of things that I would not have known had I not gone out of our compound. I was able to do laundry, ironing of clothes, I learnt how to behave properly. $\mathrm{N}$ was a respectable person and I saw how he was being humble so I learned how to be humble. He took me to places out of OkuNso', Bangolan, and Bamenda [the regional capital]. I got to these places for the first time and that was to me some achievement."

$\mathrm{F}$ represents an extreme case of the extension of fosterage networks, in this case beyond the borders of Cameroon into neighboring Gabon (see figure 2). F had been staying in Gabon during my first stay in Oku between 1991 and 1994, and was away again on my return in 2005 , but in the interim she had returned home and I was told the story of her stays abroad by her mother (who had never 


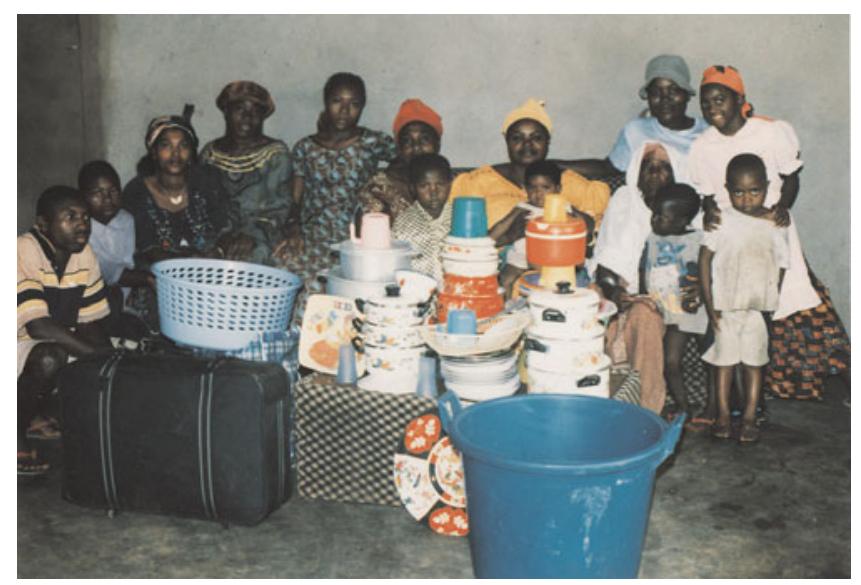

FIGURE 2 F (fifth from left) in Gabon on the eve of her return to her parents' compound with her foster family, c. 2000. Photo: unknown family photographer.

mentioned her to me in the two years of my first stay). Not only was $\mathrm{F}$ fostered to non-kin-from the Grassfields chiefdom of Babesi-and not only was she taken by them to live in Gabon, but her parents had not met her foster parents before handing their daughter over to them. In a new form of fosterage that is becoming increasingly popular with rural parents, F's foster parents were put in touch with her father through a business acquaintance of his, a market trader also from Babesi. Fosterage is often spoken of by biological and foster parents alike in the language of love and affection, so it is difficult to ascertain to what extent this middleman profited from this arrangement, or how regularly she performed this service, but it is clear that as demand for exotic, far-flung destinations increases, so too the need has increased for middlemen able to put providers of children in touch with those abroad seeking foster children.

F's case exemplifies both the highs and the lows of fosterage. The first ordeal must have been her departure from home, when she was chosen without warning from a lineup of her sisters by the foster parents who turned up unannounced at her home. As F's father put it: "One morning two women came to my compound. They were sent by A at Babesi who was my business partner. They said A had sent them because they needed a well-behaved child to assist them at home in Gabon and A had said that I had well behaved children. I told them I could not decide for them which of my many children [they should take]. [My daughters] B, J, and F stood in front of them and they selected F."

Much of her stay in Gabon appears to have been no less trying, including her subjection to accusations of stealing from her foster parents' shop and of having an affair with a Nigerian boy, resulting in her return home. Her mother, who took a more negative view of the fosterage than did her father, even told me 
of hearing rumors from her mother (a wife of the fon of Oku) about "an Oku girl in Gabon who is being kept in a cage by her foster parents." The news also reached her that $\mathrm{F}$ had gone on hunger strike to protest against her ill treatment. Under pressure from his mother-in-law, F's father then recalled his daughter. According to her mother, $\mathrm{F}$ returned home without the presents she ought to have been given. In an exchange evocative of the blurred distinction between slavery, pawnship, and fosterage, F's mother asserted,

[F's foster mother] asked me to charge her but I refused on the pretext that people are not sold. If I did that it will sound like I sold the child. I did not like that method but was ready to appreciate any gifts she offered to me.

Argenti: You could not ask for a given amount because people are not sold?

F's mother: Simply because I could not ask [for money] and asking was like selling

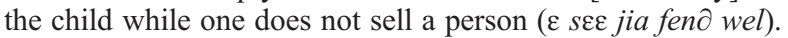

Even this experience of fosterage, however, was not without its silver lining, for $\mathrm{F}$ decided soon after her return to Oku to go back to Gabon to live independently as a trader there. According to her father, she spoke very enthusiastically of the opportunities in Gabon, of the respect that children had for their parents there, and was very impatient to go back. F's father's relationship with the trader from Babesi, meanwhile, has also remained strong. F's father again: "I will say it was a good journey because [F] was healthy and was taken care of. The luggage she brought back would not have been acquired had she stayed here. She really came home triumphantly. She was rewarded as agreed because of the cargo she brought. She has more than enough dresses she can put on for a long time to come" (21 June 2005).

Indeed, despite the small gains that children are able to make through their wits and good fortune, perhaps the greatest gains are for their parents. As F's father said, "When I give a child to a business friend our relationship is transformed ... to that of almost brother and sister." He pointed out that he had received money on credit to buy goods for resale to his trading partners as a result of fostering children to them, again blurring the distinction between fosterage and pawnship.

In her wide-ranging study of fosterage in West Africa, Goody suggests that fostering a child offers few economic advantages to a child's biological parents, but helps to build ties between kin and confers social and psychological advantages upon the child (1982: 44-47). On the other hand, Lallemand (1994: 274) concludes that fosterage is becoming increasingly market-driven, with children no longer being sent to close kin, but further afield to more distant kin or non-kin in urban centers where they might gain an education or a trade apprenticeship, a point that Goody (1982: 177-78) also concedes. The evidence from Oku seems to suggest that Lallemand's findings apply in the Grassfields, where the general pattern appears to be that more local forms of fosterage to close kin are giving way to long-distance fosterage to non-kin. As one might expect, these ruptures in the social fabric of the child are emotionally and 
psychologically taxing (Lallemand 1994: 259-60). In Lallemand's view, fosterage is no longer a traditional means of extending social networks outside the biological family, but rather a form of economic violence forced upon the kinship network by contemporary free-market capitalism. Placing Lalleman's thesis in a broader historical context, one can see that, in less than a century, the West African trade in slaves and the labor resource that these represented has been replaced to a greater or lesser extent by the imbrication of fosterage institutions and networks within global market capitalism. ${ }^{33}$

Without suggesting that the past was a utopian period free of coercive practices regarding child care, ${ }^{34}$ it is important to note that the colonial and the postcolonial periods in Cameroon not only brought about a gradual diminution of the slave trade, but simultaneously entrenched the monetization of everyday existence that now makes child labor and the fosterage of children for labor essential to the survival of the family, even at the cost of great personal risk to the foster child. ${ }^{35}$ It is clear that fosterage and slavery were distinct practices in the past and that they cannot be equated today, but it is also the case that the disappearance of slavery and the more recent descent of the postcolony into economic and political crisis has created a glut of unemployed youth that is transforming a local, benign institution into a free-market transaction devoid of the moral contract once upheld by the extended kinship network.

\section{THE TELLING OF THE TALE}

Because fosterage relations in the Grassfields are discussed in keeping with an ideology of love and care, it is all but impossible for children, and even adults, to speak explicitly of their concerns when they or their children are neglected or exploited. Fosterage is therefore a cause of real concern to the children who face the isolation, exploitation, and the sheer unpredictability that a life lived away from home can lead to. This is not to say, however, that the characters in the folktales can be seen as simple caricatures of careless, cynical parents. Children do not revel in the descriptions of evil mothers to lampoon their own biological or even foster mothers. The correspondence between the folktales and children's own lives is not a direct and literal one; the folktale blowing

\footnotetext{
33 For a specific case study of this process see Marie Rodet's (2009) historical analysis of the reinvention of slavery institutions as fosterage arrangements at the onset of emancipation in Kayes, Mali.

34 See Notermans (2004) for a case study of "fosterage politics" in Eastern Cameroon involving grandmothers within the local community.

${ }_{35}$ Caroline Bledsoe (1990) has pointed out that among the Mende of Sierra Leone the suffering involved in children's fosterage experiences is identified as one of the institution's advantages. In an observation that equally applies to the Grassfields, she points out that fosterage should be understood primarily as a relationship between the biological and foster parents (ibid.: 72, 75), and that the upward mobility afforded by sending a child to a distant city for education is achieved by the parents as much as by the child (ibid.: 74). The price to pay for this chance of upward mobility is the foster child's servitude (ibid.: 85 ).
} 
the lid on what is otherwise silenced by the ideology of love. In a straightforward phenomenological sense, the ideology of love is love, and the hatred expressed for children by parental figures in the stories is not replicated by actual parents toward their children. What the bad mother or the cannibal of the folktales actually represents, then, is not the biological, nor even the foster parent. Rather, the bad mother anthropomorphizes in concrete, tangible terms the legacy of rentier politics and the political economy of labor migration and free-market capitalism as an intrinsic and conflicted aspect of contemporary childhood in Cameroon.

In processes of mytho-praxis and of mytho-poesis that have undoubtedly been ongoing for centuries, folktales have been critically reinterpreted by children of the Grassfields, then appropriated from the control of adults and even intrinsically transformed to address the changing political and economic landscape of the life of the child in contemporary Cameroon. Far from merely providing a monolithically catastrophist backdrop to lives of hardship and insecurity, however, the folktales are in almost every case ambivalent and undetermined; they are inconclusive, "open and free" (Bakhtin 1984: 165-66): just as every tale of misfortune and injustice has its double-fond of hidden pleasures and small successes concealed within a larger discursive envelope of pain, one cannot but be struck by the recurring testimonies of foster children who view their time away from home as a form of suffering that may nevertheless yield elusive rewards. Children's folktales, which from a diachronic perspective are trenchant because they represent a body of collective memories of the slave trade to which their tellers and audience were once prey, are from a synchronic perspective still compelling today because they no less eloquently address the dilemmas of long-distance free-market fosterage. ${ }^{36}$

If the folktales that position children as liminal creatures on the fringes of the social world continue to be a source of fascination and of cultural production for them today, it is because today's fosterage relations, insofar as they transpose the relations of extractive global capitalism that denuded Africa of its children in the period of the transatlantic and local salve trades, still perpetuate the child's position of servitude in relation to its parents and lineage head. While it may well be the case then, that "many excitements which, ... are actually distressing, can become a source of pleasure for the hearers and spectators at the performance of a [storyteller's] work" (Freud 1959: 144), children's folktales continue to encapsulate the dilemmas of growing up in the Grassfields, in which the distress of exploitation and the pleasures of adventure are part and parcel of the same life course. When children swap places with their parents, moving from the dark periphery of the house to the warm glow of the maternal hearth, they not only re-enact the folktale characters' peripatetic journeys from

\footnotetext{
36 As Mats Utas points out in a forthcoming article on Liberian and Sierra Leonean folktales, "Trickster characters have always been modern" (n.d.: 20). See also van der Geest (2004).
} 
the bush or the realm of death back into the world of the living, but also their own fosterage experiences, which ultimately hold out the possibility of return from the un-homely wastes of anonymous and impossibly distant towns and cities back to the heart and hearth of the polity, arriving as adults to the place they had left as children. This role reversal is not momentary but enduring, not imaginary but real.

\section{REFERENCES}

Alber, Erdmute. 2004. Grandparents as Foster Parents: Transformations in Foster Relations between Grandparents and Grandchildren in Northern Benin. Africa 74, 1: $28-46$.

Allman, Jean. 1997. Fathering, Mothering and Making Sense of Ntamoba: Reflections on the Economy of Child-Rearing in Colonial Asante. Africa 67, 2: 296-321.

Argenti, Nicolas. 2001. Kesum-Body and the Places of the Gods: The Politics of Children's Masking and Second-World Realities in Oku (Cameroon). Journal of the Royal Anthropological Institute 7, 1: 67-94.

Argenti, Nicolas. 2005. Dancing in the Borderlands: The Forbidden Masquerades of Oku Youth and Women (Cameroon). In F. De Boeck and A. Honwana, eds., Makers and Breakers: Children and Youth in Postcolonial Africa. Oxford: James Currey, and Trenton, New Jersey: Africa World Press, 121-49.

Argenti, Nicolas. 2007. The Intestines of the State: Youth, Violence and Belated Histories in the Cameroon Grassfields. Chicago: University of Chicago Press.

Auerbach, Eric. 1968 [1946]. Mimesis: The Representation of Reality in Western Literature. Willard Trask, trans. Princeton: Princeton University Press.

Austen, Ralph. 1995. The Elusive Epic: The Narrative of Jeki la Njambe in the Historical Culture of the Cameroon Coast. Atlanta: African Studies Association.

Bakhtin, Mikhail. 1984 [1963]. Problems of Dostoyevsky's Poetics. Caryl Emerson, trans. Manchester and Minneapolis: Manchester University Press and University of Minnesota Press.

Barber, Karin. 1997. Preliminary Notes on Audiences in Africa. Africa 67, 3: 347-62.

Bellagamba, Alice. 2002. Ethnographie, histoire et colonialisme en Gambie. Paris: L'Harmattan.

Bellagamba, Alice. 2004. Entrustment and Its Changing Political Meanings in Fuladu, the Gambia. Africa 74, 3: 383-410.

Bettelheim, Bruno. 1976. The Uses of Enchantment: The Meaning and Importance of Fairy Tales. London: Penguin.

Bhabha, Homi. 1994. The Location of Culture. London: Routledge.

Bledsoe, Caroline. 1990. "No Success without Struggle": Social Mobility and Hardship for Foster Children in Sierra Leone. Man (NS) 25, 1: 70-88.

Bonhomme, Julien. N.d. Masque Chirac et danse de Gaulle: Images rituelles du Blanc au Gabon, Gradhiva (forthcoming).

Buea Archives. 1927. Political Department, Provincial Office, Cameroons. File 41/ 1927. "Bamenda criminal case No. 4/27, Rex vs. 1. Mbui of Banso, 2. Mfawme of Benshua. Charge: slave dealing," 11 Dec.

Buea Archives. 1929. Political Department, Provincial Office, Cameroons. File 110/ 1929. "Bamenda Criminal Case No. 36/1929, Rex vs. Dodo of Metaso. Charge: Slave dealing," 12 July.

Buell, Raymond Leslie. 1928. The Native Problem in Africa. 2 vols. New York: Macmillan. 
Chëm-Langhëë, Bongfen. 1995. Slavery and Slave-Marketing in Nso' in the Nineteenth Century. Paideuma 41: 177-90.

Chëm-Langhëë, Bongfen and E.S.D. Fomin. 1995. Slavery and Slave-Trade among the Banyang in the Nineteenth and Early Twentieth Centuries. Paideuma 41: 191-206.

Chilver, Elizabeth. 1961. Nineteenth-Century Trade in the Bamenda Grassfieds. Afrika und Übersee 45, 4: 233-58.

Chilver, Elizabeth. 1964. The Bali-Chamba of Bamenda: Settlement and Composition. Report No. 2 to the Bali History Committee. MS.

Démé, Victor. 2008. "Djabila" (song). From the album Victor Démé. Chapa Blues.

Drewal, Henry John. 1988. Performing the Other: Mammi Wata Worship in West Africa. Drama Review 32, 2: 160-85.

Drewal, Henry John, ed. 2008. Sacred Waters: Arts for Mami Wata and other Divinities in Africa and the Diaspora. Bloomington: Indiana University Press.

Dundes, Alan. 2007. Structuralism and Folklore. In S. Bronner, ed., The Meaning of Folklore: The Analytical Essays of Alan Dundes. Logan: Utah State University Press, 126-44.

Fagunwa, D. O. 1982. Forest of a Thousand Demons: A Hunter's Saga. Translation from Yoruba Wole Soyinka. New York: Random House.

Falola, Toyin and Akanmu Adebayo. 2000. Culture, Politics and Money among the Yoruba. New Brunswick and London: Transaction Publishers.

Falola, Toyin and Paul E. Lovejoy, eds. 1994. Pawnship in Africa: Debt Bondage in Historical Perspective. Boulder: Westview Press.

Fortes, Meyer. 1938. Social and Psychological Aspects of Education in Taleland. Supplement to Africa 11, 4.

Fortes, Meyer. 1949. The Web of Kinship among the Tallensi. Oxford: Oxford University Press.

Frank, Barbara. 1995. Permitted and Prohibited Wealth: Commodity-Possessing Spirits, Economic Morals, and the Goddess Mami Wata in West Africa. Ethnology 34, 4: $331-47$.

Freud, Sigmund. 1959 [1908]. Creative Writers and Day-Dreaming. In James Strachey et al., eds., Complete Psychological Works of Sigmund Freud, Standard Edition. Vol. 9. London: Hogarth, 143-53.

Gluckman, Max. 1963. Rituals of Rebellion in South-East Africa. In Order and Rebellion in Tribal Africa. London: Cohen and West, 110-36.

Goody, Esther. 1982. Parenthood and Social Reproduction: Fostering and Occupational Roles in West Africa. Cambridge: Cambridge University Press.

Gore, C. and J. Nevadomsky. 1997. Practice and Agency in Mammy Wata Worship in Southern Nigeria. African Arts 30, 2: 60-69.

Gow, Peter. 2001. An Amazonian Myth and Its History. Oxford: Oxford University Press.

Grier, B. 1992. Pawns, Porters and Petty Traders: Women in the Transition to Cashcrop Agriculture in Colonial Ghana. Signs 17, 2: 304-28.

Heath, Shirley Brice. 1983. Ways with Words: Language Life and Work in Communities and Classrooms. Cambridge: Cambridge University Press.

Hogendorn, Jan, and Marion Johnson. 1986. The Shell Money of the Slave Trade. Cambridge: Cambridge University Press.

Koité, Habib. 1998. "Wassiyé" (song). From Ma Ya. Putumayo Artists.

Kuper, Adam. 1987. Cannibals, Beast and Twins. In South Africa and the Anthropologist. London: Routledge, 167-96.

Lallemand, Suzanne. 1994. Adoption et mariage: Les Kotokoli du centre du Togo. Paris: L'Harmattan. 
Lovejoy, Paul and Toyin Falola. 2003. Pawnship, Slavery and Colonialism in Africa. Trenton, N.J.: Africa World Press.

Lovejoy, Paul and Jan Hogendorn. 1993. Slow Death for Slavery: The Course of Abolition in Northern Nigeria, 1897-1936. Cambridge: Cambridge University Press.

Masquelier, Adeline. 1992. Encounter with a Road Siren: Machines, Bodies and Commodities in the Imagination of a Mawri Healer. Visual Anthropology Review 8, 1: 56-69.

Masquelier, B. M. 1978. Structure and Process of Political Identity: Ide, a Polity of the Mentshum Valley (Cameroon). PhD diss., University of Pennsylvania.

Mbarga, Prince Nico. 1976. "Sweet Mother" (song). From the album Aki Special. First released by Rogers All Stars (Nigeria) Ltd. Released in 1987 on Rounder Records, Cambridge, Mass.

Mbunwe-Samba, Patrick. 1998. Shadows in the Firelight: A Selection of Cameroon Folktales. Bamenda, Cameroon: ACT Office, P.O. box 510.

McCarthy Brown, Karen. 2001 [1991]. Mama Lola: A Vodou Priestess in Brooklyn. Berkeley and London: University of California Press.

Miers, Suzanne, and Richard Roberts. 1988. The End of Slavery in Africa. Madison: University of Wisconsin Press.

Murphy, Laura. 2007. Into the Bush of Ghosts: Specters of the Slave Trade in West African Fiction. Research in African Literatures 38, 4: 141-52.

Newell, Stephanie. 1997. Making Up Their Own Minds: Readers' Interpretations and the Difference of View in Ghanaian Popular Narratives. Africa 67, 3: 389-405.

Notermans, Catrien. 2004. Fosterage and the Politics of Marriage and Kinship in East Cameroon. In F. Bowie, ed., Cross-Cultural Approaches to Adoption. London: Routledge, 48-63.

Notermans, Catrien. 2008. The Emotional World of Kinship: Children's Experiences of Fosterage in East Cameroon. Childhood 15, 3: 355-77.

Nwokeji, G. Ugo and David Eltis. 2002. Characteristics of Captives Leaving the Cameroons for the Americas, 1822-1837. Journal of African History 43: 191-210.

Ogrizek, M. 1981-1982. La Mammy Wata: Les envoûtées de la sirène, Cahiers de l'O.R. S.T.O.M., Série Sciences Humaines, Médicines et santé 19, 4: 433-43.

Paulme, Denise. 1976. La mère dévorante: Essai sur la morphologie des contes Africains. Paris: Gallimard.

Piaget, Jean. 1951. Play, Dreams and Imitation in Childhood. C. Gattegno and F. M. Hodgson, trans. New York: Norton.

Rattray, R. S. 1930. Akan and Ashanti Folk-Tales. Oxford: Oxford University Press.

Raum, O. 1940. Chaga Childhood. London: Oxford University Press.

Renne, Elisha P. 2005. Childhood Memories and Contemporary Parenting in Ekiti, Nigeria. Africa 75, 1: 63-82.

Rodet, Marie. 2009. The End of Slavery and the Circulation of Juvenile and Female Workforce in the Region of Kayes, French Sudan (1890-1955). Paper presented to the 11th Stanford-University of California Law and Colonialism Symposium, "Trafficking in Women and Children after the End of Slavery: Historical and Contemporary Perspectives from Africa and Beyond," 19-21 Mar.

Rudin, Harry. 1938. Germans in the Cameroons 1884-1914: A Case Study in Modern Imperialism. London: Johnathan Cape.

Ruel, Malcolm, 1969. Leopards and Leaders: Constitutional Politics among a CrossRiver People. London: Tavistock.

Salmons, Jill. 1977. Mammy Wata. African Arts 10, 3: 8-15, 87.

Scheub, Harold. 2002. The Poem in the Story: Music, Poetry, and Narrative. Madison: University of Wisconsin Press. 
Schwartzman, Helen B. 1978. Transformations: The Anthropology of Children's Play. New York and London: Plenum Press.

Shaw, Rosalind. 2008. Mami Wata and the Sierra Leone Diamonds: Wealth and Enslavement in Men's Dreams and the State Economy. In Henry John Drewal, ed., Sacred Waters: Arts for Mami Wata and other Divinities in Africa and the Diaspora. Bloomington: Indiana University Press, 19-25.

Todd, Loreto. 1979. Some Day Been Dey: West African Pidgin Folktales. London: Routledge and Kegan Paul.

Tutuola, Amos. 1978 [1954]. My Life in the Bush of Ghosts. London: Faber and Faber.

Tutuola, Amos. 1986. Yoruba Folktales. Ibadan: Ibadan University Press.

Tutuola, Amos. 2004 [1952]. The Palm-Wine Drinkard and His Dead Palm-Wine Tapster in the Dead's Town. Ibadan: Spectrum.

Utas, Mats. N.d. Abject Heroes: Marginalised Youth, Modernity and Violent Pathways of the Liberian Civil War. In Jason Hart, ed., Years of Conflict: Political Violence and Displacement. Oxford: Berghahn Books (forthcoming).

Vail, Leroy, and Landeg White. 1991. Power and the Praise Poem: Southern African Voices in History. Charlottesville: University of Virginia.

van der Geest, Sjaak. 2004. Orphans in Highlife: An Anthropological Interpretation. History in Africa 31: 425-40.

Verhoef, Heidi. 2005. A Child Has Many Mothers: Views of Fostering in Northwestern Cameroon. Childhood 12, 3: 369-90.

Warnier, Jean-Pierre. 1985. Echange, Développements et Hiérarchie dans le Bamenda Pré-colonial (Cameroun). Studien Zur Kulturkunde 76. Wiesbaden: Franz Steiner Verlag.

Warnier, Jean-Pierre. 1995. Slave-Trading without Slave-Raiding in Cameroon. Paideuma 41: 251-72.

Warnier, Jean-Pierre. 2007. The Pot-King: The Body and Technologies of Power. Leiden and Boston: Brill.

Watson-Gegeo, Karen Ann and Stephen Boggs. 1977. From Verbal Play to Talk Story: The Role of Routines in Speech Events among Hawaiian Children. In Susan ErvinTripp and Claudia Mitchell Kernan, eds., Child Discourse. New York: Academic Press, 67-90.

Wehrs, Donald. 2008. Pre-Colonial Africa in Colonial African Narratives: From Ethiopia Unbound to Things Fall Apart, 1911-1958. Burlington, Vt.: Ashgate. 